\title{
PENAMBAHAN BAKTERI ASAM LAKTAT UNTUK MENINGKATKAN KUALITAS, KEAMANAN DAN DAYA SIMPAN ROTI
}

[Addition of lactic acid bacteria to improve bread quality, safety, and shelf life]

\section{Mutia Devi Ariyana*, Moegiratul Amaro, Wiharyani Werdiningsih, Baiq Rien Handayani, Nazaruddin, dan Sri Widyastuti}

Program Studi Ilmu dan Teknologi Pangan Fakultas Teknologi Pangan dan Agroindustri Universitas Mataram *email: mutiadevi0705@gmail.com

Diterima 10 Juli 2018/ Disetujui 25 Oktober 2018

\begin{abstract}
The changes of people consumtion patterns demands a healthier bread product and tends to be organic food without use synthetic food additives that brings various consequences to health. This condition leads to the development of food additives which has effectiveness equivalent to synthetic food additive but safe for health especially if consumed long term. Lactic acid bacteria is a bacteria that hass been widely used in fermented food production process. Making bread using lactic acid bacteria begins with sourdough or acid dough consisting of flour and water fermented with lactic acid bacteria either derived from a particular natural contaminant from flour or from a starter culture containing one or more known lactic acid bacteria. Various product of actic acid bacteria metabolism such as lactic acid, acetic acid, exopollysaccharide and antimicrobial compounds such as bacteriocin make lactic acid bacteria application in baking process have to the potential to improve microbiological quality and bread shelf-life. This research aims to study the effect of lactic acid bacteria addition as a natural preservative in the baking process. The ability of lactic acid bacteria to evolve naturally from fermented flour and water promises the potential for easy sourdough preparation and can be used continuously as a natural preservative that will save production cost. The parameters to be determined include evaluation of lactic acid bacteria and yeast growth on dough and determination of moisture content as well as total bacteris, mold and E.coli an bread.
\end{abstract}

Key words: bread, lactic acid bacteria, preservatives, shelf-life, food safety

\section{ABSTRAK}

Pergeseran pola konsumsi masyarakat menuntut adanya produk roti yang lebih sehat dan cenderung bersifat organik tanpa penggunaan Bahan Tambahan Makanan (BTM) sintetis yang membawa berbagai konsekuensi terhadap kesehatan. Kondisi ini mengarah pada berkembangnya pencarian BTM yang memiliki efektifitas yang setara dengan BTM sintetis namun aman bagi kesehatan terutama jika dikonsumsi jangka panjang. Bakteri Asam Laktat (BAL) merupakan golongan bakteri yang telah digunakan secara luas dalam proses produksi makanan fermentasi. Pembuatan roti menggunakan BAL diawali dengan sourdough atau adonan asam yang terdiri atas tepung dan air yang difermentasi dengan BAL baik yang berasal dari kontaminan alami tertentu dari tepung atau dari suatu kultur starter yang mengandung satu atau lebih BAL yang sudah diketahui jenisnya. Berbagai produk hasil metabolisme BAL seperti asam laktat, asam asetat, eksopolisakarida dan senyawa antimikroba seperti bakteriosin menjadikan aplikasi BAL pada proses pembuatan roti berpotensi meningkatkan kualitas mikrobiologis dan daya simpan roti. Penelitian ini secara khusus bertujuan untuk mempelajari pengaruh penambahan BAL sebagai pengawet alami dalam proses pembuatan roti. Kemampuan BAL untuk berkembang secara alami dari tepung dan air yang difermentasi menjanjikan potensi penyediaan sourdough yang mudah dibuat dan dapat digunakan secara kontinyu sebagai pengawet alami sehingga akan menghemat biaya produksi. Parameter yang akan ditentukan meliputi evaluasi pertumbuhan BAL dan yeast pada adonan dan penentuan kadar air serta total bakteri, kapang dan E. coli pada roti.

Kata kunci: roti, bakteri asam laktat, pengawet, daya simpan, keamanan pangan.

\section{PENDAHULUAN}

Roti telah menjadi sumber karbohidrat alternatif yang cukup populer di Indonesia. Pergeseran pola konsumsi masyarakat mengakibatkan tuntutan akan roti yang lebih sehat dan cenderung bersifat alami atau organik terus mengalami peningkatan. Hal ini tidak terlepas dari kekhawatiran masyarakat akan tingginya tingkat penggunaan Bahan 
Tambahan Makanan (BTM) kimiawi seperti potasium bromat dan kalsium propionat yang memberikan dampak buruk bagi kesehatan. Potasium bromat yang digunakan oleh produsen roti sebagai agensia pengembang ternyata bersifat karsinogenik sehingga dapat memicu kanker, sedangkan kalsium propionat yang umum digunakan sebagai pengawet pada produk roti berpotensi menimbulkan Attention-Defisit Hyperactivity Disorder (ADHD) yang menyebabkan seorang anak menjadi hiperaktif dan sulit berkonsentrasi.

Pembatasan penggunaan BTM kimiawi mengarah kepada pencarian BTM alami yang memiliki efektifitas serupa. Senyawa hidrokoloid merupakan salah satu jenis BTM alternatif dari bahan alami yang diketahui dapat memperbaiki karakteristik adonan dan hasil akhir roti (Rodge, 2012; September, 2007; Rehman and Mudassar, 2003). Penelitian Widyastuti dkk. (2015) dan Werdiningsih dkk. (2016) menunjukkan bahwa karaginan yang merupakan hidrokoid hasil isolasi dari Euchema cottonii dan Halymenia $s p$. memiliki kemampuan untuk meningkatkan meningkatkan volume pengembangan, memperbaiki struktur dan tekstur crumb, mempertahakan kadar air dan elastisitas roti selama penyimpanan dan menghambat pertumbuhan beberapa jenis jamur penyebab kerusakan pada roti. Akan tetapi, penggunaan isopropil alkohol pada proses ekstraksi karaginan menjadikan aplikasi senyawa hidrokoloid ini pada bahan pangan dibeberapa negara masih menjadi kontroversi.

Bakteri Asam Laktat (BAL) merupakan golongan bakteri yang telah digunakan secara luas dalam proses produksi makanan fermentasi salah satunya pada proses pembuatan roti. Pembuatan roti menggunakan BAL diawali dengan pembuatan suatu produk intermediet yang dikenal dengan sebutan sourdough atau adonan asam. Sourdough merupakan suatu campuran yang terdiri atas tepung dan air yang difermentasi dengan BAL baik yang berasal dari kontaminan alami tertentu dari tepung atau dari suatu kultur starter yang mengandung satu atau lebih BAL yang sudah diketahui jenisnya (Vuyst and Neysen, 2005). Metode pembuatan roti dengan memanfaatkan BAL pada soudough ini memang bukan metode yang umum dilakukan di Indonesia, akan tetapi dibeberapa negara terutama di eropa, metode ini tetap banyak digunakan dalam teknologi pembuatan roti modern karena roti yang dihasilkan memiliki kualitas sensori yang sangat baik dan dan memiliki masa simpan yang lebih panjang (Vuyst and Neysen, 2005). Peningkatan kualitas dan masa simpan ini terkait dengan keberadaan senyawa-senyawa hasil metabolisme BAL seperti asam laktat, asam asetat, eksopolisakarida dan substansi antimikroba seperti bakteriosin (Saeed et al., 2014).

Mengingat bahaya yang mengancam dibalik penggunaan BTM sintetis dan meningkatnya kesadaran akan produk makanan yang aman bagi kesehatan telah mendorong penelitian tentang potensi penggunaan bahan non sintetis pada proses pengolahan makanan. Penelitian tentang potensi bahan tambahan alami atau nonsintetik yang aman serta dapat memperpanjang masa simpan produk roti juga telah mulai dilakukan, salah satunya adalah penggunaan BAL. Gocmen et al. (2007) dan Thiele et al. (2002) dalam Aplevicz et al. (2013) melaporkan bahwa aplikasi BAL pada roti gandum menimbulkan beberapa pengaruh, termasuk membantu proses peragian dan pemasaman serta meningkatkan kualitas rasa dan tekstur roti, menunda terjadi pengerasan dan staling, meningkatkan ketersediaan nutrien dan meningkatkan resistensi terhadap kerusakan akibat mikroba. Kemampuan BAL dalam meningkatkan resistensi terhadap kerusakan akibat mikroba disebabkan oleh produksi senyawa antibakteri, substansi antijamur, dan aktivitas antiropiness (Vuyst and Neysen, 2005). Fakta ini menunjukkan bahwa penambahan BAL berpotensi meningkatkan kualitas mikrobiologi dan daya simpan roti. 


\section{BAHAN DAN METODE}

\section{Alat dan Bahan}

Bahan yang akan digunakan dalam pembuatan sourdough diantaranya adalah tepung terigu, tepung mocaf, air dan kultur BAL jenis L. delbrueckii dan L. plantarum. Bahan pembuatan roti diantaranya tepung terigu protein tinggi, gula, susu, kuning telur, ragi (fermipan), air, mentega dan garam. Bahan pengujian mikrobiologis diantaranya media Potato Dextrose Agar (PDA), larutan buffer phosphate, $\mathrm{HCl}$, aquadest dan plastik OPP dengan ukuran $12 \mathrm{~cm} \times 17 \mathrm{~cm}+4 \mathrm{~cm}$ ( untuk lipatan dan lem) dan dengan ketebalan 0,32 mikron.

Alat yang digunakan dalam proses pembuatan sourdough antara lain: wadah kaca steril, pengaduk kaca steril dan fermentor. Alat yang digunakan dalam proses pembuatan roti antara lain: timbangan, bread maker, piring, baskom, sendok, cetakan aluminium, loyang, kuas mentega dan oven. Alat yang digunakan dalam uji mikrobiologis adalah erlenmeyer, beaker glass, hot plete, magnetic stirer, autoclave, label, bunsen, timbangan analitik, plastik steril, pinset/gunting, stomacher, rak tabung reaksi, tabung reaksi, petridish, colony counter, waterbath, mikroskop, inkubator dan pipet mikro.

\section{Metode}

Penelitian dilakukan dengan Rancangan Acak Lengkap yang terdiri dari dua faktor yaitu: sumber BAL pada sourdough (subtrat tepung terigu, subtrat tepung terigu + mocaf serta substrat tepung terigu + kultur $L$. delbrueckii dan L. plantarum) dan lama penyimpanan $(0,1,2,3,4,5,6$, dan 7 hari). Sebagai kontrol digunakan roti yang dibuat hanya dengan yeast tanpa penambahan sourdough. Masing-masing perlakuan tersebut diulangi sebanyak tiga kali sehingga diperoleh 96 unit percobaan.

Parameter yang diukur dalam penelitian ini meliputi kadar air, total bakteri, total coliform, dan total jamur. Pengukuran pada adonan dan pada roti. Pengukuran yang
ISSN: 2443-1095

dilakukan pada adonan berupa evaluasi pertumbuhan BAL dan yeast.

\section{Proses Pembuatan Sourdough}

Pembuatan Sourdough dilakukan dengan modifikasi metode Aplevicz et al. (2014). Adapun tahap pembuatannya adalah sebagai berikut:

1. Tepung terigu, tepung terigu yang telah dicampur mocaf dan tepung terigu yang telah ditambahkan kultur $L$. delbrueckii dan L. plantarum dipersiapakn sebagai substrat untuk pembuatan sourdough

2. Masing-masing substrat kemudian ditambahkan air hangat $\left(30-40^{\circ} \mathrm{C}\right)$ dengan perbandingan $1: 1$.

2. Campuran kemudian diinkubasi selama 24 jam pada suhu ruang untuk memulai prefermentasi.

3. Setelah 24 jam prefermentasi, campuran ditambahkan dengan substrat dan air hangat dengan perbandingan 1: 0,5: 0,5 , kemudian didiamkan pada suhu $30^{\circ} \mathrm{C}$.

4. Perlakuan yang sama diulangi hingga hari ke-4.

5. Jika volume sourdough telah mencapai $2-3$ kali volume semula dan terdapat gelembung udara maka sourdough sudah siap digunakan. Aroma sourdough juga dicek apakah berbau asam segar atau berbau busuk untuk memastikan ada kontaminasi atau tidak.

\section{Proses Pembuatan Roti}

Tahap pembuatan:

1. Dilakukan penimbangan semua bahan sesuai dengan komposisi yang telah ditentukan

2. Dilakukan pencampuran terigu, gula dan susu dengan bread maker menggunakan kecepatan rendah sampai tercampur rata

3. Masukkan ragi dan soudough yang telah dilarutkan dengan air hangat dan kuning telur sedikit demi sedikit sambil diaduk sampai membentuk gumpalan-gumpalan

4. Setelah air tercampur, dimasukkan mentega dan garam, kemudian diaduk 
menggunakan kecepatan sedang hingga adonan kalis

5. Dilakukan fermentasi awal dengan cara membulatkan adonan dan ditutup plastik selama 30 menit

6. Setelah $\mathbf{3 0}$ menit adonan dikempeskan hingga udara keluar, dibagi dua kemudian diproofing kembali selama 30 menit dalam wadah yang ditutup plastik.

7. Setelah mengembang, adonan dikempiskan, ditimbang $70 \mathrm{gr}$ dan dibulatkan lalu dimasukkan ke dalam cetakan aluminium

8. Dilakukan fermentasi akhir dengan memasukkan adonan pada mesin proofer dengan suhu $30^{\circ} \mathrm{C}$ selama 90 menit

9. Pemanggangan dilakukan dengan suhu oven $180^{\circ} \mathrm{C}$ selama 20 menit.

\section{HASIL DAN PEMBAHASAN}

Empat jenis sourdough digunakan untuk menggantikan peran ragi komersial (fermipan) dalam pembuatan roti. Sourdough atau adonan asam merupakan suatu campuran yang terdiri atas tepung dan air yang difermentasi dengan Bakteri Asam Laktat (BAL). BAL yang berkembang di dalam adonan dapat berasal dari kontaminan alami tertentu dari tepung atau dari suatu kultur starter yang mengandung satu atau lebih BAL yang sudah diketahui jenisnya (Vuyst and Neysen, 2005). Jenis sourdough pertama dan kedua hanya difermentasi oleh BAL yang berasal dari kontaminan alami dari tepung. Sourdough pertama dihasilkan hanya dari campuran tepung terigu dan air (1:1), sedangkan jenis sourdough kedua dihasilkan dari campuran tepung terigu, mocaf dan air $(0,5: 0,5: 1)$. Adapun jenis sourdough ketiga dan keempat difermentasi oleh BAL yang berasal dari suatu kultur starter yang mengandung suatu BAL yang sudah diketahui jenisnya. Sourdough ketiga merupakan campuran dari terigu dan air (1:1) yang ditambahkan starter BAL dari jenis Lactobacillus plantarum, sedangkan sourdough keempat ditambahkan dengan
ISSN: 2443-1095

Lactobacillus delbruckii. Kultur BAL ditambahkan sebesar $1 \%$ dari berat tepung.

\section{Karakteristik Fisik, Organoleptik dan Mikrobiologis Sourdough}

Sourdough yang digunakan merupakan jenis sourdough tipe I jika ditinjau berdasarkan jenis teknologi yang digunakan dalam proses pembuatannya yaitu menggunakan bagian dari hasil fermentasi sebelumnya (Rollan et al., 2010). Sourdough ini dicirikan dengan penyegaran kultur yang dilakukan setiap hari secara kontinyu untuk menjaga mikroorganisme tetap berada pada tahap aktif yang ditunjukkan dengan suatu aktifitas metabolik tinggi yang berkaitan dengan peragian (Vuyst \& Neysen, 2005). Tingginya aktivitas metabolik ditunjukkan dengan peningkatan volume yang signifikan akibat tingginya produksi gas. Hal ini ditandai dengan pembentukan sejumlah gelembung udara yang terdapat didalam maupun dipermukaan adonan (Gambar 1). Hasil pengamatan menunjukkan bahwa sourdough terigu maupun sourdough yang ditambahkan dengan Lactobacillus plantarumdan Lactobacillus delbruckii menunjukkan pola pembentukan gelembung udara yang serupa dimana gelembung udara berukuran kecil dan berada dalam jumlah cukup banyak tidak hanya di bagian tengah adonan tetapi juga dipermukaan, sedangkan sourdough terigu yang dicampur dengan tepung mocaf menunjukkan pola yang berbeda dimana gelembung udara yang terbentuk berukuran lebih besar namun hanya berada dibagian tengah dari adonan (Gambar 1).

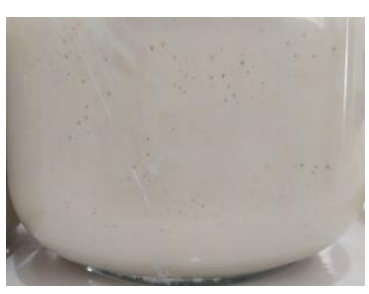

a

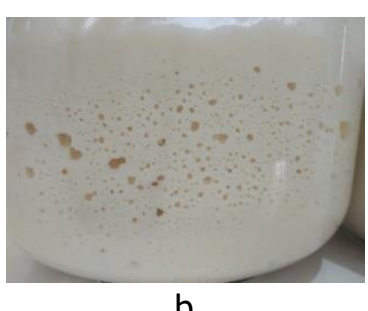

b
Gambar 1 Karakteristik Sourdough Terigu (a) dan Sourdough Terigu Mocaf (b) 
Selain pola pembentukan gelembung udara, sourdough tepung terigu serta sourdough yang telah ditambahkan dengan BAL juga memiliki beberapa karakteristik lain yang berbeda dari sourdough terigu yang dicampur dengan mocaf. Dari segi kenampakan dan konstistensi, sourdough tepung terigu serta sourdough yang telah ditambahkan dengan BAL berwarna putih dan cenderung encer, sedangkan sourdough terigu yang dicampur dengan mocaf berwarna putih kekuningan dan lebih kental. Sourdough tepung terigu serta sourdough yang telah ditambahkan dengan BAL juga memiliki aroma yang manis dengan sedikit aroma asam, sedangkan sourdough hasil pencampuran tepung terigu dan mocaf memiliki aroma manis namun dengan aroma asam yang cenderung lebih kuat. Hasil pengujian menunjukkan bahwa sourdough hasil pencampuran tepung terigu dan mocaf memiliki $\mathrm{pH}$ yang lebih rendah yaitu berada pada kisaran 3,5-3,9. Hal ini kemungkinan besar disebabkan oleh $\mathrm{pH}$ bahan baku yaitu tepung mocaf yang cenderung rendah yaitu pada kisaran pH 4 (BSN, 2011). Jenis sourdough selain yang dicampurkan dengan tepung mocaf memiliki pH pada kisaran 4-4,5. Hal ini sesuai dengan pernyataan Vuyst \& Neysen (2005) yang menyatakan bahwa sourdough tipe 1 umumnya memiliki pH 4.

Perbedaan karakteristik secara keseluruhan antara jenis sourdough ini diduga disebabkan oleh perbedaan kandungan BAL baik dari segi jenis maupun jumlah. Selain kandungan BAL, perbedaan ini juga dapat disebabkan oleh keberadaan khamir yang secara alami tumbuh pada sourdough karena pada beberapa kasus ditemukan khamir dalam jumlah yang signifikan (Vuyst and Neysen, 2005). Adapun jumlah BAL dan khamir pada sourdough dapat diamati pada Gambar 2.
ISSN: 2443-1095

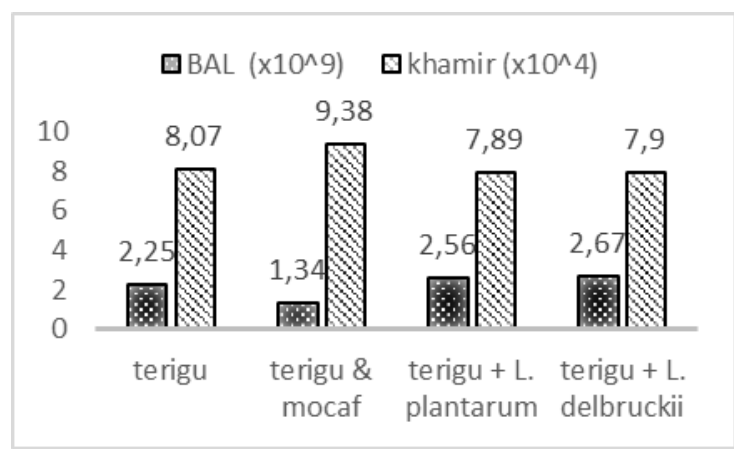

Gambar 2. Total Bakteri Asam Laktat dan Khamir pada Sourdough

Total BAL pada seluruh perlakuan mencapai $10^{9} \mathrm{CFU} / \mathrm{g}$. Kondisi ini sejalan dengan pernyataan Vuyst and Neysen (2005) yang menyatakan pada adonan yang difermentasi asam densitas sel biasanya melebihi $10^{8} \mathrm{CFU} / \mathrm{g}$ adonan. Adapun total BAL pada sourdough dengan penambahan BAL baik $L$. plantarum maupun $L$. delbruckii sedikit lebih tinggi dibandingkan dengan sourdough terigu tanpa penambahan BAL, sedangkan total BAL terendah ditemukan pada sourdough terigu yang dicampur dengan mocaf yaitu hanya $50 \%$ dari total BAL yang ditemukan pada jenis sourdough lainnya. Selain perhitungan total BAL juga dilakukan pengamatan morfologi yang meliputi bentuk dan uji gram dimana diproleh hasil bahwa bakteri yang tumbuh merupakan bakteri dari jenis basil dan merupakan kelompok bakteri gram positif sehingga memperkuat dugaan bahwa bakteri yang terdapat dalam sourdough adalah BAL.

Selain BAL, dari sampel sourdough yang diuji juga ditemukan khamir dengan jumlah sekitar $10^{4}$. Keberadaan khamir pada sourdough berbeda dengan keberadaan BAL, dimana khamir berada pada jumlah tertinggi pada sourdough dengan campuran mocaf, sedangkan pada jenis lain jumlah khamir cenderung lebih rendah.

\section{Aplikasi Bakteri Asam Laktat pada Proses Pembuatan Roti melalui Substitusi Ragi Komersial dengan Sourdough}

Proses pembuatan roti dilakukan dengan subsitusi ragi komersial yang selama ini telah umum digunakan (fermipan) dengan 
Versi Online:

http://www.profood.unram.ac.id/index.php/profood e-ISSN: 2443-3446

menggunakan sourdough. Subsitusi ragi komersial dilakukan dengan penambahan sourdough sebesar $40 \%$ dari berat tepung terigu (Aplevicz et al., 2014).
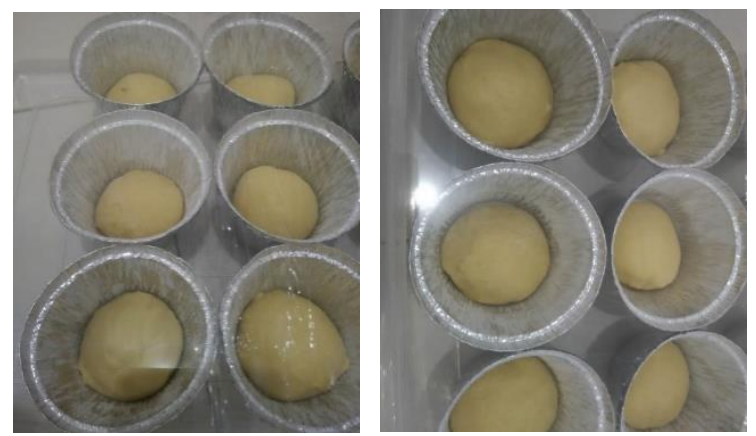

Gambar 3. Adonan Roti yang Dibuat dengan Sourdough Terigu (a) dan Sourdough Terigu Mocaf (b)

Pemanfaatan kultur BAL alami pada sourdough dalam proses pembuatan roti menjadikan waktu proofing yang dibutuhkan lebih lama jika dibandingkan dengan penggunaan ragi komersial. Kultur BAL alami diduga membutuhkan waktu yang lebih lama untuk beradaptasi atau cenderung membutuhkan fase lag yang lebih panjang selain itu kultur alami juga tidak mengandung pengembang sintetis seperti yang terdapat pada ragi komersial. Oleh karena itu, Untuk mencapai kondisi pengembangan yang optimal dengan menggunakan sourdough dibutuhkan waktu hingga 12 jam.
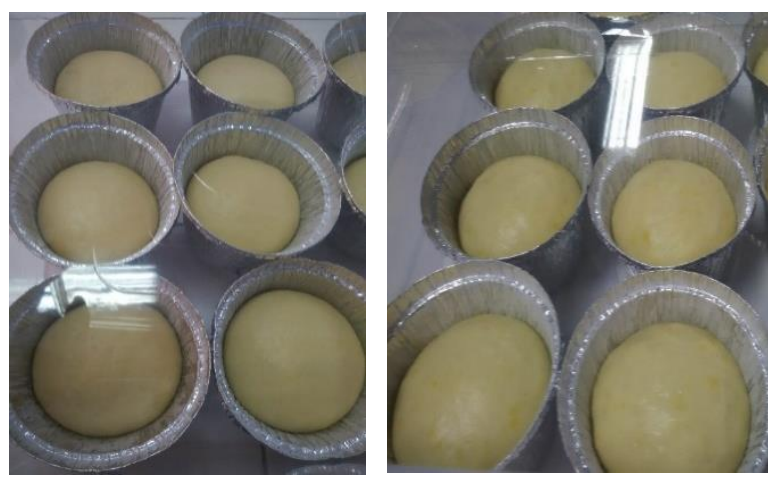

Gambar 4. Pengembangan Adonan Roti yang Dibuat dengan Sourdough Terigu(a) dan Sourdough Terigu Mocaf (b)
Pro Food (Jurnal IImu dan Teknologi Pangan) Vol 4 No. 2 November 2018 ISSN: 2443-1095

Roti yang dibuat dengan menggunakan sourdough memiliki penampilan fisik yang hampir serupa dengan roti kontrol (dengan ragi komersial), namun sedikit berbeda bila ditinjau dari segi sensoris. Roti dari masing-masing perlakuan dikemas dengan menggunakan plastik OPP kemudian disimpan pada suhu ruang selama 7 hari.

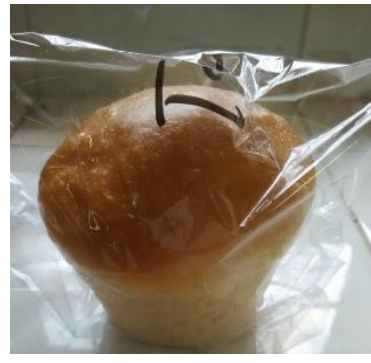

a

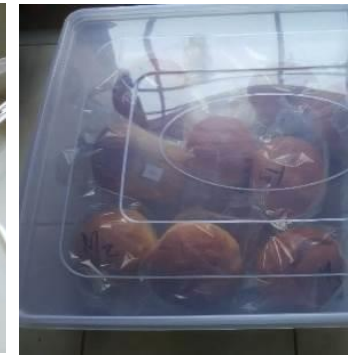

b
Gambar 5. Pengemasan (a) dan Penyimpanan (b) Roti

\section{Pengaruh Penambahan BAL terhadap Kualitas Mikrobiologi dan Daya Simpan Roti}

Penambahan BAL pada roti melalui aplikasi sourdough diharapakan dapat meningkatkan kulitas mikrobiologis dan daya simpan roti. Penentuan kualitas mikrobiologis dan daya simpan roti dilakukan dengan melakukan perhitungan terhadap total mikroba dan total jamur pada roti dari seluruh perlakuan. Hasil perhitungan total mikroba dan total jamur pada roti ditunjukkan pada Tabel 1.

Tabel 1. Total Bakteri (CFU/g) pada Roti Selama 7 Hari Masa Simpan

\begin{tabular}{|l|c|c|c|c|c|c|c|c|}
\hline Perlakuan & Hari-0 & Hari-1 & Hari-2 & Hari-3 & Hari-4 & Hari-5 & Hari-6 & Hari-7 \\
\hline Kontrol & 0 & 0 & 0 & 0 & 0 & 0 & $4,7 \times 10^{5}$ & $4,7 \times 10^{5}$ \\
\hline $\begin{array}{l}\text { Terigut } \\
\text { mocaf }\end{array}$ & 0 & 0 & 0 & 0 & 0 & 0 & 0 & $4,68 \times 10^{3}$ \\
\hline $\begin{array}{l}\text { Terigu } \\
\text { Terigut } \\
\text { L.plantarum }\end{array}$ & $29,5 \times 10^{6}$ & $72 \times 10^{5}$ & $84,5 \times 10^{6}$ & $101 \times 10^{6}$ & $156 \times 10^{5}$ & $59 \times 10^{7}$ & $89 \times 10^{7}$ & $52,5 \times 10^{8}$ \\
\hline $\begin{array}{l}\text { Terigut } \\
\text { L.delbruckii }\end{array}$ & $28 \times 10^{6}$ & $43,5 \times 10^{6}$ & $76 \times 10^{6}$ & $81 \times 10^{6}$ & $71,5 \times 10^{6}$ & $26 \times 10^{7}$ & $26 \times 10^{8}$ & $43,5 \times 10^{8}$ \\
\hline
\end{tabular}

Berdasarkan data pada tabel di atas, penggunaan sourdough terigu serta 
e-ISSN: 2443-3446

sourdough terigu yang dicampur mocaf dapat menekan pertumbuhan bakteri jika dibandingkan roti kontrol. Roti kontrol menunjukkan adanya pertumbuhan bakteri sejak hari ke-6 penyimpanan yaitu $4,7 \times 10^{5}$. Penggunaan sourdough terigu dapat menghambat pertumbuhan bakteri hingga hari ke- 5 penyimpanan, sedangkan pada hari ke- 6 dan 7 teramati adanya pertumbuhan bakteri yaitu sebesar $5,25 \times 10^{3}$. Hampir serupa dengan pengaruh sourdough terigu, sourdough terigu yang telah dicampur dengan mocaf juga dapat menghambat pertumbuhan bakteri bahkan hingga hari $k-6$ penyimpanan, sedangkan pada hari ke-7 teramati pertumbuhan bakteri

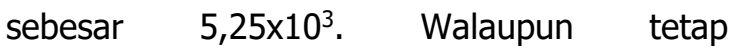
menunjukkan adanya pertumbuhan bakteri, penggunaan sourdough dalam pembuatan roti menunjukkaan adanya penghambatan pertumbuhan bakteri yang cukup besar yaitu hanya sampai pada $10^{3}$ sehingga roti masih cenderung aman untuk dikonsumsi hingga hari ke-7 penyimpanan karena menurut persyaratan SNI total mikroba atau yang dinyatakan dengan angka lempeng total yang diperbolehkan untuk roti tawar adalah $10^{6}$ CFU/g (BSN, 2011).

Kondisi yang sangat berbeda tampak pada data total mikroba dari roti yang dibuat menggunakan sourdough dengan penambahan starter BAL. Data total mikroba menunjukkan adanya pertumbuhan bakteri sejak roti selesai diproduksi hingga hari terakhir penyimpanan. Total mikroba yang teramati terus meningkat mulai dari kisaran $10^{6}$ hingga $10^{8}$ pada akhir penyimpanan. Penyebab yang pasti dari kondisi ini apakah terkait penambahan starter BAL atau tidak belum dapat dipastikan. Pengujian lebih lanjut seperti penggunaan medium selektif BAL diperlukan untuk memtikan penyebab dari kondisi ini.

Penggunaan sourdough tidak hanya dapat menekan pertumbuhan bakteri tetapi juga dapat menekan pertumbuhan mikroorganisme perusak utama pada roti yaitu jamur. Aplikasi seluruh jenis sourdough menunjukkan adanya penghambatan terhadap pertumbuhan jamur terutama jika
ISSN: 2443-1095

dibandingkan dengan roti kontrol. Roti kontrol menunjukkan adanya pertumbuhan jamur pada hari ke- 6 sebesar $5 \times 10^{4}$ dan terus

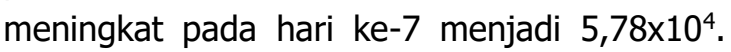
Total jamur pada roti kontrol ini telah melewati syarat yang diperbolehkan berdasarkan SNI yaitu $10^{4}$ (BSN, 2011).

Penggunaan sourdough terigu dapat menghambat pertumbuhan bakteri hingga hari ke- 5 penyimpanan, sedangkan pada hari ke- 6 dan 7 teramati adanya pertumbuhan bakteri yaitu sebesar $7,5 \times 10^{2}$. Hampir serupa dengan pengaruh sourdough terigu, sourdough terigu yang telah dicampur dengan mocaf juga dapat menghambat pertumbuhan bakteri dimana pada hari $\mathrm{k}-6$ penyimpanan total jamur yang teramati sebesar $1,43 \times 10^{2}$, sedangkan pada hari ke-7 teramati adanya peningkatan

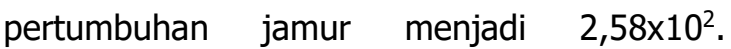
Serupa dengan yang terjadi pada penghambatan pertumbuhan bakteri, walaupun tetap menunjukkan adanya pertumbuhan jamur, penggunaan sourdough dalam pembuatan roti menunjukkaan adanya penghambatan yang cukup besar yaitu hanya sampai pada $10^{2}$ sehingga roti masih cenderung aman untuk dikonsumsi hingga hari ke-7 penyimpanan karena menurut persyaratan SNI total jamur yang diperbolehkan untuk roti tawar adalah $10^{4}$ CFU/g (BSN, 2011). Bahkan pada roti yang dibuat menggunakan sourdough dengan penambahan starter BAL menunjukkan adanya penghambatan pertumbuhan jamur hingga hari ke-7 penyimpanan (Tabel 2)

Tabel 2. Total Jamur (CFU/g) pada Roti Selama 7 Hari Masa Simpan

\begin{tabular}{|l|c|c|c|c|c|c|c|c|}
\hline Perlakuan & Hari-0 & $\begin{array}{l}\text { Hari- } \\
1\end{array}$ & $\begin{array}{l}\text { Hari- } \\
2\end{array}$ & $\begin{array}{l}\text { Hari- } \\
3\end{array}$ & $\begin{array}{l}\text { Hari- } \\
4\end{array}$ & $\begin{array}{l}\text { Hari- } \\
5\end{array}$ & Hari-6 & Hari-7 \\
\hline Kontrol & 0 & 0 & 0 & 0 & 0 & 0 & $5 \times 10^{4}$ & $5,78 \times 10^{4}$ \\
\hline $\begin{array}{l}\text { Terigut } \\
\text { mocaf }\end{array}$ & 0 & 0 & 0 & 0 & 0 & 0 & $1,43 \times 10^{2}$ & $2,58 \times 10^{2}$ \\
\hline Terigu & 0 & 0 & 0 & 0 & 0 & 0 & $7,5 \times 10^{2}$ & $7,5 \times 10^{2}$ \\
\hline $\begin{array}{l}\text { Terigut } \\
\text { L.plantarum }\end{array}$ & 0 & 0 & 0 & 0 & 0 & 0 & 0 & 0 \\
\hline $\begin{array}{l}\text { Terigut } \\
\text { L. delbruckii }\end{array}$ & 0 & 0 & 0 & 0 & 0 & 0 & 0 & 0 \\
\hline
\end{tabular}


Penghambatan pertumbuhan bakteri dan jamur pada roti yang dibuat dengan menggunakan sourdough tidak terlepas dari keberadaan BAL yang tumbuh pada adonan baik secara alami maupun dengan penambahan starter tertentu. Keberadaan BAL pada adonan dibuktikan dengan hasil perhitungan total BAL pada medium MRSA yang menunjukkan jumlah BAL yang cukup besar yaitu 1,34-2,67 x 109 CFU/g (Gambar 4.2). Gocmen et al. (2007) dan Thiele et al. (2002) dalam Aplevicz et al. (2013) melaporkan bahwa aplikasi BAL pada roti gandum menimbulkan beberapa pengaruh, termasuk membantu proses peragian dan pemasaman serta meningkatkan kualitas rasa dan tekstur roti, menunda terjadi pengerasan dan staling, meningkatkan ketersediaan nutrien dan meningkatkan resistensi terhadap kerusakan akibat mikroba. Kemampuan BAL dalam meningkatkan resistensi terhadap kerusakan akibat mikroba disebabkan oleh produksi senyawa antibakteri, substansi antijamur, dan aktivitas antiropiness (Vuyst and Neysen, 2005). Pernyataan ini diperkuat oleh Saeed et al. (2014) yang menyatakan bahwa peningkatan kualitas dan masa simpan ini terkait dengan keberadaan senyawasenyawa hasil metabolisme BAL seperti asam laktat, asam asetat, eksopolisakarida dan substansi antimikroba seperti bakteriosin.

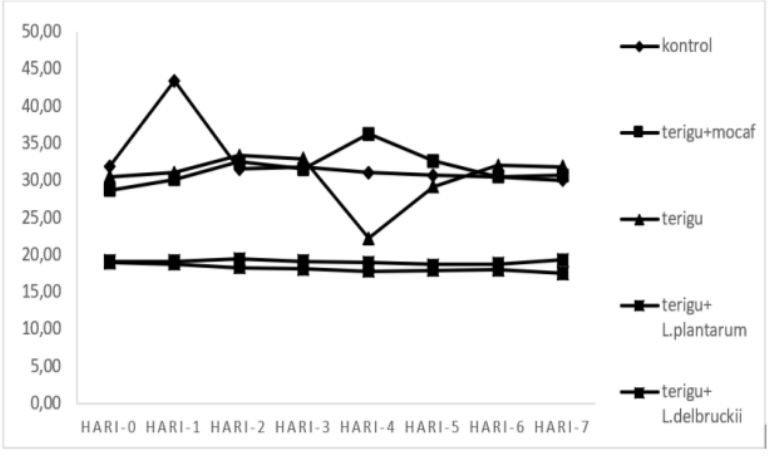

Gambar 6. Kadar Air Roti (\%) dari Seluruh Perlakuan

Selain aktivitas senyawa-senyawa yang bersifat antibakteri dan antijamur yang diproduksi oleh BAL, peningkatan kualitas mikrobiologis dan masa simpan roti yang dibuat dengan menggunakan sourdough juga
ISSN: 2443-1095

dapat merupakan pengaruh dari penurunan kadar air dan derajat keasaman. Kadar air roti terutama yang dibuat dengan sourdough dengan penambahan starter BAL menunjukkan adanya penurunan kadar air hingga $10 \%$ yang tentu saja berdampak terhadap pertumbuhan mikroorganisme (Gambar 6). Selain itu, penggunaan sourdough juga mengakibatkan adanya penurunan derajat keasaman dimana roti kontrol memiliki $\mathrm{pH}$ mendekati netral sedangkan roti dengan sourdough memiliki $\mathrm{pH}$ yang lebih rendah 1 sampai 2 tingkat dari $\mathrm{pH}$ roti kontrol (Gambar 7).

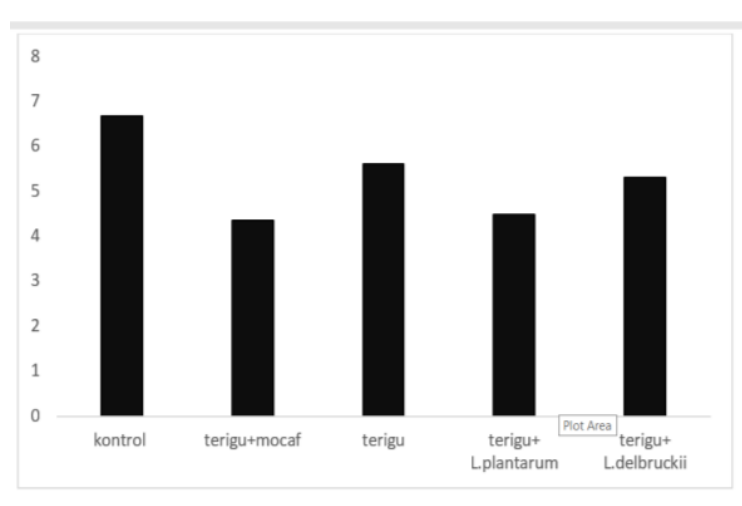

Gambar 7. Tingkat Keasaman Sourdough

Berdasarkan hasil pengamatan roti selama masa simpan, pada roti kontrol terdapat 2 jenis kapang penyebab kerusakan, sedangkan pada roti dengan penambahan sourdough hanya terdapat satu jenis kapang (Gambar 8). Data ini menunjukkan bahwa penambahan sourdough mampu menekan pertumbuhan beberapa jenis kapang penyebab kerusakan pada roti. Adapun senyawa bioaktif pada yang dihasilkan oleh BAL yang bersifat antagonis terhadap kapang salah satunya adalah bakteriosin.

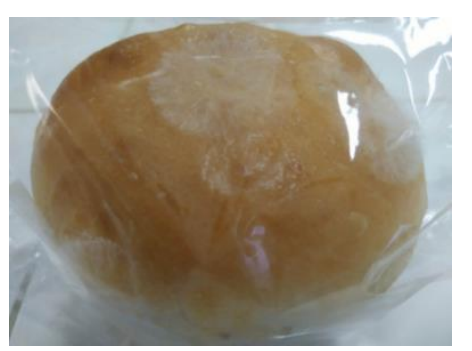

Gambar 8. Pertumbuhan Kapang pada Roti dengan Sourdough Selama Masa Simpan 


\section{KESIMPULAN}

Berdasarakan hasil pengamatan dan pembahasan dapat ditarik beberapa kesimpulan sebagai berikut:

1. Roti yang dibuat dengan menggunakan sourdough memiliki angka total mikroba yang lebih rendah dibandingkan dengan kontrol.

2. Roti yang dibuat dengan menggunakan sourdough memiliki angka total jamur yang lebih rendah dibandingkan dengan kontrol.

3. Penghambatan pertumbuhan bakteri dan jamur pada roti yang dibuat dengan sourdough dimungkinkan dengan tingginya total BAL pada sourdough serta adanya penurunan kadar air serta derajat keasaman.

\section{DAFTAR PUSTAKA}

Adams, Martin R., Maurice O. Moss. 2008. Food Microbiology Third Edition. RSC Publishing. Guildford, UK.

Aplevicz, K.S., P.J. Ogliari and E.S.S. Anna. 2013. Influence of Fermentation Time on Characteristics of Sourdough Bread. Brazilian Journal of Pharmacheutical Sciences 49(2): 233-239

Axelsson, L. 1998. Lactic Acid Bacteria: Classification and Physiology. dalam S. Salminen and A Von Wright (Ed). Lactic Acid Bacteria Microbiology and Functional Aspects. 2nded: Revised and Expanded. New York: Marcell Dekker, Inc.

Aplevicz, K.S., J.Z. Mazo, E.C. Ilha, A.Z. Dinon and E.S.S. Anna. 2014. Isolation and Characterization of Lactic Acid Bacteria and Yeast from the Brazilian Grape Sourdough. Brazilian Journal of Pharmacheutical Sciences 50(2): 321327

Campbell, N.A., Reece, J.B., Mitchell, L.G. 2002. Biologi. Alih bahasa lestari, $\mathrm{R}$. et al. safitri, A., Simarmata, L., Hardani, H.W. (eds). Erlangga, Jakarta.

Dengate S. and Ruben A. 2002. Controlled trial of cumulative bahavioural effects of a
ISSN: 2443-1095

common bread preservative. J. Paediatr Child Health 38: 373-376.

Gaman, P. M. dan Sherrington, K.B. 1992. IImu Pangan, Pengantar I/mu Pangan, Nutrisi dan Mikrobiologi. Yogyakarta: Gajah Mada University Press

Kartika. 1998. Pedoman Uji Inderawi Bahan Pangan. Yogyakarta. UDM

Kurokawa, Y., Maekawa, A., Takahashi .and M. ,Hayasi, Y. 1990. Toxicity and Carcinogenicity of Potassium Bromate; A New Renal Carcinogen. Environ. Health Persp. 87:309-335.

Parsons, J.L. and Chipman, J.K. 2000.The role of glutathione in DNA damage by potassium bromate in vitro. Mutagenesis 15(4):311-316.

Rahayu, E.S. dan Margino. 1997. Bakteri Asam Laktat Isolasi dan Identifikasi. PAU Pangan dan Gizi UGM, Yogyakarta.

Rehman, S. and A. Mudassar. 2003. Effect of Carboxxy methyl Cellulose and Carrageenan gum on the Shelf life of Bread. Pak J. Food Science 13(1): 4952

Rodge, A.B, Sonkamble SM., Salve RV., and Syed Imran Hasmi. 2012. Effect of hydrocolloid (guar gum) Incorcopration on the Quality Characteristics of Bread. $J$ Food Process Techno/ 3:2.

Rollan, G. C.L. Gerez, A.M. Dallagnol, M.I. Torino and G. Fost. 2010. Update in Bread Fermentation by Lactic Acid Bacteria. Current Research, Technology and Education Topics in Applied Microbiology and Microbial Biotechnology.1168-1174

Saeed, M., M.I. Khan, I. Pasha, M.R. Khan, A. Shabbir and W.A. Khan. 2014. Lactic Acid Bacteria in Sourdough Fermentation: A safe Approach for Food Preservation. Pakistan Journal of Food Science. 24 (4): 211-217

Suardana, W. 2007. Isolasi dan Identifikasi Bakteri Asam Laktat dari Cairan Rumen Sapi

Bali sebagai Kandidat Biopreservatif . J. Veteriner 8 (4): 155-159 
September, Cindy. 2007. The Effect of enzymes, gums and proteins on the water absorption, loaf volume and shelf life of bread. Master Thesis. Univ. Johannesburg Oct

Syarbini, H., 2013. A-Z Bakery. PT. Tiga Serangkai Pustaka Mandiri: Semarang

Uchida, H. A., Sugiyama, H., Kanehisa, S., Harada, K., Fujiwara, K. and Ono, T. 2006. An elderly patient with severe acute renal failure due to sodium bromated intoxication. Intern Med. 45: 151-154

Vuyst, L.D. and P. Neysens. 2005. The Sourdough Microflora: Biodiversity and Metabolic Interaction. Trends in Food Science \& Technology.16: 43-56

Werdiningsih, W., S. Widyastuti, Nazzaruddin, B.R. Handayani dan M. Amaro. 2016. Penambahan Hidrokoloid Karaginan Untuk Meningkatkan Kualitas Mikrobiologi dan Daya Simpan Roti. Laporan Penelitian. Fakultas Teknologi Pangan dan Agroindustri, Universitas Mataram.

Widyastuti, S., Nazzaruddin, B.R. Handayani, W. Werdiningsih., dan M.D. Ariyana. 2015. Penambahan Hidrokoloid Karaginan Untuk Meningkatkan Kualitas, Keamanan dan Daya Simpan Roti. Laporan Penelitian. Fakultas Teknologi Pangan dan Agroindustri, Universitas Mataram.

Yusmarini, R. Indriati ,T. Utami Dan Y. Marsono.2009. Isolasi Dan Identifikasi Bakteri Asam Laktat Proteolitik Dari Susu Kedelai Yang Terfermentasi Secara Spontan. Jurnal Natur Indonesia 12(1): 28-33 